\begin{tabular}{|c|c|c|}
\hline Beitr. Ent. & Keltern & ISSN 0005-805X \\
\hline $\mathbf{6 1}(2011) 2$ & S. $259-270$ & 10.11 .2011 \\
\hline
\end{tabular}

\title{
Aspects of the biology of Megalodontes thor TAEGER, 2002
}

\section{(Hymenoptera: Symphyta: Megalodontesidae)}

With 5 figures

Andrew D. Liston and Jochen Späth

\begin{abstract}
Summary
Some features of the biology of Megalodontes thor TAEGER, 2002, a rare xerothermophilous sawfly species, are described and discussed, particularly feeding, sexual and egg-laying behaviour of imagines and habits of the larvae. At the type locality (main study area) in Southern Germany the larvae feed exclusively on Peucedanum oreoselinum (Apiaceae). At other localities further Peucedanum species are probably fed upon. Flight period at the type locality is approximately two months, which is exceptionally long for a univoltine sawfly. Copulation takes place mostly on inflorescences and mainly during dusk or dawn, whereas feeding activity takes place at higher temperatures and in full daylight. Temporal separation of these two types of behaviour has not been recorded in other Symphyta. Yellow inflorescences are strongly favoured by $M$. thor for feeding. Where a choice is available, inflorescences with half hidden nectaries (Ranunculus) are visited far more frequently than those with completely hidden nectaries (Asteraceae). The application of a secretion around the egg after oviposition, recorded here for the first time in the Megalodontesidae, has previously been observed in the Symphyta only in the closely related Pamphiliidae. The significance of the secretion is discussed. Differences are highlighted in the biologies of M. thor and M. cephalotes (FABRICIUs, 1781), the only Megalodontesidae for which comparable data are available. The highly endangered status of many Central European xerothermophilous sawflies is discussed in the light of observations on $M$. thor.
\end{abstract}

\section{Zusammenfassung}

Aspekte zur Lebensweise von Megalodontes thor TAEGER, 2002, einer seltenen, xerothermophilen Blattwespenart, werden dargestellt und erörtert. Der Schwerpunkt liegt dabei auf dem Fress-, Sexual- und Eiablageverhalten der Imagines sowie dem Larvalverhalten. Am Typenfundort (Hauptuntersuchungsgebiet) in Süddeutschland ernähren sich die Larven ausschließlich von Peucedanum oreoselinum (Apiaceae). An anderen Standorten werden vermutlich auch weitere Vertreter dieser Pflanzengattung gefressen. Die Flugperiode von $M$. thor dauert am Typenfundort ca. zwei Monate, was für eine univoltine Blattwespenart außergewöhnlich lange ist. Kopulationen wurden meist auf Blüten und hauptsächlich in der Abend- und Morgendämmerung beobachtet. Futtersuche und Eiablage finden nur bei vollem Tageslicht und höheren Temperaturen statt. Diese zeitliche Trennung von Kopulation sowie Futtersuche und Eiablage war bei Blattwespen bisher unbekannt. Zur Nahrungssuche bevorzugen die Imagines gelbe Blüten. Wenn die Auswahl besteht, suchen sie weitaus häufiger Blüten mit halbverborgenem Nektar (Ranunculus) auf als Blüten mit völlig verborgenem Nektar (Asteraceae). Nach der Eiablage betupfen die Weibchen das Eiumfeld mit einem Sekret, was bei Blattwespen bisher nur von den nahe verwandten Pamphiliidae bekannt war. Die Bedeutung solcher Sekrete wird erörtert. Die Biologie von $M$. thor wird mit der von $M$. cephalotes (FABRICIUs, 1781) verglichen, der einzigen Megalodontesidae von der vergleichbare Daten vorliegen. Die starke Gefährdung der zentraleuropäischen xerothermophilen Blattwespenarten wird am Beispiel von $M$. thor erörtert.

Key words

Hymenoptera, Megalodontesidae, Megalodontes thor, biology, Peucedanum, Germany 


\section{Introduction}

Megalodontesidae are specialised inhabitants of warm, dry places with steppe-like vegetation. The family contains a single exclusively Palaearctic genus of about 37 species (TAEger et al. 2010). 22 European species were revised and keyed by TAEger (2002). The Megalodontesidae and Pamphiliidae form the Pamphilioidea. The superfamily and each family are regarded as representing well supported monophyletic lineages (TAEGER 2002). The main behavioural differences between the two families are briefly outlined below (see section 3.7). The six Megalodontes species recorded in northern Central Europe are at or near the northern and western edge of a principally southern and eastern Western Palaearctic range (Blank et al. 2001, TAEger 2002). They are all regarded as more or less endangered (TAEger et al. 1998). Since pioneering work on the biology of Megalodontes by Hiendlmayr (1878), Kriechbaumer (1878) and Stritt (1937), little additional information has been made available, except for a single detailed study of $M$. cephalotes (Fabricius, 1781) (as M. klugi Leach, 1817) by Pschorn-Walcher (1990).

In recent years, the authors were able to make observations on the biology of an unusually large local population of Megalodontes thor TAEGER, 2002 at the type locality in southern Germany, where the species was first found in 1986 by H. KoLBecK.

\section{Methods}

Main study site was the Nature Reserve "Rosenau" (Scheuerer \& SрÄтH 2001; type locality of Megalodontes thor), Landkreis Dingolfing-Landau, Lower Bavaria, Germany (012³4'49"E, $48^{\circ} 39^{\prime} 43^{\prime \prime N}$. $346 \mathrm{~m}$ a.s.l.) and unless otherwise stated, data are from there. Most of the fieldwork was done in 2001 and 2002. Recognition of the sex of the imagines, important in connection with observations on their behaviour, was based on the reduced yellow bands on the abdomen and more elongate body of the male (Fig. 1). The place of deposition of freshly laid eggs was marked with ribbons of narrow, coloured, plastic tape tied around the petiole. Subsequent regular control of individuals which survived, through the larval stages, enabled the approximate duration of development of the immature stages under natural conditions to be determined. A few visits were also made during the hours of darkness, to observe behaviour of imagines and larvae. Material is preserved in the Senckenberg Deutsches Entomologisches Institut (SDEI), Müncheberg.

\section{Results}

\section{1 hostplants and habitats}

The only larval hostplant known for certain is Peucedanum oreoselinum (L.) Moench (Apiaceae). This was confirmed by observing oviposition and development of larvae both at the Nature Reserves "Rosenau" and "Isarauen bei Goben". However, it is probable that the record (STRITT 1937) of M. plagiocephalus (Fabricius, 1804) reared from P. alsaticum L. also refers to $M$. thor. The male mentioned by STRITT was examined by A. TAEgER and identified, with certain reservations, as M. thor. At a locality in N. Bavaria (Franconia, Landkreis Bad Kissingen, Trimberg) two adult females were collected by the authors from foliage of $P$. carvifolia Vill. Provisionally, $M$. thor is regarded as a second grade monophage, applying the classification of VIITASAARI (2002). 
P. oreoselinum is a major component of the herb layer of the open Festuco-Brometea association at the main study site (Rosenau), but also occurs along linear features (railway embankment, edge of field road) and edge features (around and inside the margins of an oak-pine copse). That $M$. thor also utilises these subsidiary plant populations was shown by the abundance of larvae on parts of the railway embankment. Nevertheless, it was estimated that $M$. thor was only present on at most 3 ha of the total 11 ha which comprise the Nature Reserve. Imagines were found mainly in relatively large stands of $P$. oreoselinum, or in much smaller areas with flowering Ranunculus.

\section{2 distribution and status as an endangered species}

The extensive W. Palaearctic distribution of $M$. thor is described by TAEger (2002). German records are concentrated in Baden-Wurttemberg and Bavaria, with the most northerly populations in the southern Rhineland-Pfalz (BLANK et al. 2001; SDEI database). There is a marked dominance of old data. Records for North Bavaria are scattered throughout the Jurassic chalk and limestone areas of Franconia and the Upper Palatinate, but south of the Danube $M$. thor seems to be restricted to the valleys of the Isar and Lech. Apart from the Isar Valley populations in Dingolfing-Landau, the only known occurrences in South Bavaria are one female from München Pullach (Upper Isar Valley), 23.07.1858, leg. J. Kriechbaumer (ZSM) and three males and one female from Königsbrunn (Lech Valley), 05.07.1991, leg. et coll. M. Kraus (Coll. KraUs). Although recorded at several localities in N. Bavaria by M. KRAUS in recent years, very few individuals were encountered. $M$. thor is restricted to the surviving fragments of herb-rich xerotherm plant associations (principally Mesobrometum, but occurs marginally also in semiruderal Geranion sanguineum associations, such as abandoned vineyards (personal observations by the authors in Franconia).

The population at Rosenau seems exceptionally large compared to others recently observed elsewhere in Germany, where its increasingly rare and isolated occurrences suggest that it is strongly endangered. Peucedanum oreoselinum is absent in large areas between the nature reserves at Rosenau and Goben, about $5 \mathrm{~km}$ apart. Much smaller populations of both P. oreoselinum and $M$. thor occur at the latter site. It seems unlikely that any gene-flow at present takes place between these populations of $M$. thor. The adults at both these localities vary morphologically very little.

\section{3 phenology, sex-ratio, abundance}

First sightings of $M$. thor imagines in recent years were on 17.05.2000, 19.05.2001, 18.05.2002, 11.05.2004 and last sightings on 23.06.2000, 14.07.2001, 5.07.2002, 19.07.2004. The flight period of about two months is remarkably long, compared to most other univoltine symphytans. Perhaps slight protandry occurs: males were always observed first, the females 1 or 2 days later. Numbers of adults peaked at the end of May / start of June. More than 100 imagines were counted at the Rosenau on several occasions during this period, but the actual number present was probably very much greater. The secondary sex ratio derived from such counts varied from 1.13-1.56 males / 1.00 female, but males may be over-represented, because they spend a greater proportion of their time visiting inflorescences. In fine weather females become very active and difficult to observe as they search for suitable oviposition sites. It is remarkable that imagines of $M$. thor are by far the most abundant sawflies at Rosenau from the end of May until they disappear in July, to be replaced as the most abundant species thereafter by the ubiquitous Athalia rosae (Linnaeus, 1758) (Tenthredinidae; larvae on Brassicaceae and frequently a pest of cultivated forms). 
Oviposition of $M$. thor was first recorded on 26.05.2001 and 22.05.2002 and the freshly emerged larvae on 31.05.2001 and 03.06.2002. The first fully-grown larvae left their tubes on 01.07. in both years, but at this time numerous eggs and very young larvae were also present. Eggs hatch ca. 5-7 days after oviposition. Larval development takes approximately 3-4 weeks. We have no data on the longevity of imagines, but it seems probable that the extended periods of activity of both adults and larvae are the result of a temporally highly scattered emergence pattern, rather than extreme longevity of individuals.

\section{4 predation}

Two imagines of $M$. thor were found to have been captured by Misumena vatia (CLERCK, 1757) (Araneae, Thomisidae). On 01.06.2008 one male was found dead on a Ranunculus inflorescence, being fed upon by an adult Phymata crassipes (Fabricius, 1775) (Hemiptera, Reduviidae). The bug's proboscis was inserted in the sawfly's thorax. Only one instance of predation of immature stages was observed. During a night-time visit to the study site, an earwig completely consumed an egg.

\section{5 adult behaviour}

Imagines are capable of swift, strong flight, typically within a height of $30-50 \mathrm{~cm}$ above ground level, or approximately $10-20 \mathrm{~cm}$ above the densest layer of vegetation. Visits to inflorescences occupy much time of both sexes. Large numbers moved away from the areas containing the larval hostplant to feed at the flowers of Ranunculus acris and $R$. repens growing about $50 \mathrm{~m}$ away on a nutrient rich roadside at the periphery of the nature reserve. Ranunculus was not at that time present in the intervening area. Feeding takes place mainly at temperatures above $20^{\circ} \mathrm{C}$ during daylight, but at temperatures exceeding $27^{\circ} \mathrm{C}$ is increasingly interrupted by phases of inactivity of up to several minutes, spent on the shaded underside of an inflorescence. By contrast, copulation was observed mainly at dusk and dawn, or during periods of low daytime light intensity.

\subsection{1 feeding}

Megalodontes species all have more or less lengthened mouthparts (JERVis \& VilheLmsen 2000) which they use to feed at relatively deeply seated nectaries, such as those of some Asteraceae. Fully extended, the galeo-maxillary organs of $M$. thor project approximately $2.0 \mathrm{~mm}$ below the labrum. Nevertheless, flowers with more open nectaries are also visited avidly (particularly Ranunculus). Pollen is consumed in significant quantities by both sexes, as confirmed by the dissection of adults, although only feeding on nectar was directly observed. Feeding was almost exclusively at yellow inflorescences. Frequent visits were observed only on yellow flowered Ranunculus ( $R$. acris and $R$. repens) (Ranunculaceae), and a wide variety of yellow flowered Asteraceae. Visits to inflorescences of other colours (including white), are very rare. Where yellow-flowered Asteraceae (plants with completely hidden nectaries) occurred next to Ranunculus (plants with half-hidden nectaries), the latter seemed to be preferred. The Asteraceae were increasingly visited as the period of adult activity progressed and Ranunculus inflorescences became scarce. In descending order of frequency visited after Ranunculus were Bupthalmum 
salicifolium, Leontodon incanus, L. hispidus, Senecio jacobaea, Leucanthemum vulgare and Inula salicina. Only single feeding visits at Tragopogon pratensis, Achillea millefolium (Asteraceae), Euphorbia cyparissias (Euphorbiaceae), Potentilla anserina (Rosaceae) and Helianthemum nummularium ssp. obscurum (Cistaceae) were observed. Although abundant during the flight season of M. thor, and with potentially accessible nectaries, yellow inflorescences of Sedum acre, S. sexangulare (Crassulaceae), Galium verum (Rubiaceae), Reseda lutea (Resedaceae), Potentilla erecta (Rosaceae), Hypericum perforatum (Hypericaceae) and Verbascum sp. (Scrophulariaceae) were not observed to be fed at, although brief landings on some of these sometimes occurred. No visits to the inflorescences of the larval host, or other Apiaceae, were observed, although these are highly attractive to imagines of numerous other sawfly species (Tenthredinoidea, especially some Tenthredinidae, Cimbicidae and Argidae, but also other Megalodontes species: see 3.7). Individuals of $M$. thor often carry large amounts of pollen, especially on the hairs of the underthorax, and can be presumed to be effective pollinators, because feeding activity involves frequent changes of inflorescences and usually inflorescences of a single plant species are visited during a feeding sequence.

Prolonged observation failed to reveal any definite use for the highly developed mandibles: but see below (3.5.4). During feeding at flowers, they are kept closed in front and above the labiomaxillary organs. Possibly they serve in part as a shield to protect the more delicate functional mouthparts, and may also be used to push away floral stamens which hinder probing of the nectary. Also possible, but unproven, is a function in scooping pollen towards the mouth. Nectarfeeding is interrupted by irregular periods of "grooming" using mainly the front, and rather less the middle legs. It is possible that pollen is forwarded to the mouthparts and ingested during such activity. Visits to inflorescences are not only for feeding: copulation nearly always takes place on flower heads.

\subsection{2 night resting places}

Imagines became inactive in fine weather after ca. 18.30 hours (CET). Reduced light intensity is presumably the trigger, because temperatures were often still $22-24^{\circ} \mathrm{C}$, sufficient for full activity during daylight. The majority of $M$. thor observed during the hours of darkness $(\mathrm{n}=81)$ spent the night where they were most abundant during the day, especially in and around patches of Ranunculus. Only $16 \%$ were however found directly on Ranunculus inflorescences. $41 \%$ rested on the stalks and ears of grasses, the rest on a wide variety of other plants, particularly on or near the inflorescences of Asteraceae. On average, both sexes are found $31 \mathrm{~cm}(10-70 \mathrm{~cm})$ above ground level, corresponding to the upper third of the herb layer at this site. $57 \%$ rested on the terminal parts of plants. They remain immobile during the night, as indicated by the numerous yellow balls of excrement (mostly pollen?) found grouped around them in the early morning. Activity is first resumed when the temperature rises above $20^{\circ} \mathrm{C}$.

Repeatedly observed at night and dawn were aggregations of several imagines of mixed sex. These groups often consisted of one female and several males (see also 3.5.3). Individuals were usually densely clustered, almost touching each other, but singletons that could be considered part of the aggregation were positioned up to $40 \mathrm{~cm}$ from its centre. Individuals react immediately to movements of others in the same group. Possibly the stimulus is visual (or even acoustic?), because the individuals that reacted were often on different plants (vibrations transmitted through the substrate are therefore not involved). 


\subsection{3 pairing}

Copulation lasted at least several minutes, but its duration is possibly highly temperature dependant. Whereas oviposition and feeding were more actively pursued at higher temperatures and / or higher light intensity (usually mid-day), copulation occurred usually at dusk or dawn and during daylight hours was only observed in cooler or overcast conditions. Although at mid-day in good weather males very frequently made advances on females engaged in feeding at inflorescences, these encounters were never seen to result in copulation. The females always reacted with apparently aggressive defensive behaviour, finally flying away. The attitude adopted in copulation (Fig. 1) is as in the Tenthredinoidea, i. e. the two bodies form a straight axis and the only point of contact is between the abdomen tips. Pairs were observed in nearly motionless copula for periods of more than three hours during cool, cloudy weather. On two occasions on cool mornings prolonged homosexual copulation between morphologically apparently normal males was also observed. Aggregations of several males on the undersides of inflorescences of Asteraceae frequently form during the evening around a female resting on the inflorescence upper centre. These aggregations probably provide the setting for most successful pairings (see also 3.5.2).

\subsection{4 defensive behaviour}

Adults of both sexes feeding at inflorescences do not always fly away when disturbed by other insects, but may perform a "threatening" display. The wings, previously held nearer to the body, are spread, the rear legs drawn towards the body so that the insect is crouched, with its head tilted up towards the potential enemy, and the mandibles are opened wide. Although the mandibles are incapable of penetrating human skin, they are presumably useful in repulsing some insects. A female M. thor in SDEI has the severed head of an ant (Formica sp.) attached to the antennal flagellum by its deeply embedded mandibles.

\subsection{5 oviposition}

The search for oviposition sites is conducted at higher temperatures during the period of greatest light intensity. Oviposition was only observed between 11:00 and 14:00 hours. Leaves of P. oreoselinum positioned in unshaded, less dense vegetation are strongly favoured. The yellowish white, subcylindrical eggs (Fig. 2) measuring approximately $2 \mathrm{~mm}$ x $0.8 \mathrm{~mm}$ are laid exclusively on the lower (rosette) leaves, never on leaves of the flower stalk, which however only develops fully after mid June. $95 \%(n=61)$ are placed on the leaf underside, the remainder on the leafstalks. No eggs were laid on tender, newly formed leaflets. The leaflets formed second during the development of the rosette leaves are strongly favoured (60\% of eggs). Orientation of the egg on the leaflet is nearly always with the long axis approximately parallel to the leaflet's midrib (corresponding to the body position adopted by the female during oviposition), but its position on the leaflet (edge, middle, base, etc.) appears to be random. Only one egg is laid per plant per female during each oviposition sequence, but $29 \%$ of the compound leaves on which eggs were found bore more than one egg. Occasionally they were even on the same leaflet. The emergence of larvae from such "groups" of eggs was usually on different days, suggesting that they were mostly not laid at the same time.

Most of the time devoted to egg-laying was taken up by numerous short flights between potential oviposition sites. One female was observed for 20 minutes visiting about 14 different plants of $P$. oreoselinum, rejecting most plants quickly after a brief landing, the others rejected only after a closer scrutiny of one or more leaflets. She laid no eggs during this time. Another female 
laid 3 eggs in about 20 minutes, also rejecting several plants. She then visited a Ranunculus flower to feed. The sawfly investigates a leaflet first from the upperside, touching the leaf surface frequently with the tip of the abdomen. Either it then flies on to the next potential oviposition site, or it moves to the underside of the leaflet if this has been found to be suitable. Oviposition then follows almost immediately, with the body aligned parallel to the midrib of the chosen leaflet. There follows a period of rapid crawling around the leaflet and leaf-stalk accompanied by much lateral movement of the abdomen tip ("brushing"), during which clear, quick-drying secretion is smeared erratically around the egg on the leaflet under-surface and the adjoining petiole. A few very fine strands of secretion often also appear to connect the egg with surrounding parts of the leaflet (Fig. 3). About 100-120 seconds elapse between landing and take-off.

No clear incision was observed to be made with the ovipositor in the leaf, but this may be very slight and could have been overlooked. A zone of discolouration of the leaf epidermis near the egg, visible in material preserved in alcohol, suggests that some disruption of the leaf tissue may take place (Fig. 2). The egg is however definitely only gummed to the leaf epidermis; no part of the chorion is inserted in the leaf.

\section{6 larval behaviour}

The first instar larva briefly inhabits a loosely woven, rather flat shelter of silk on the underside of a leaflet, where the first feeding takes place, restricted to grazing of the parenchyma of leaves and petioles, usually without perforating or severing these. Within 2 or 3 days a more extensive, three-dimensional web is formed, generally constructed around the upper surface of the leaflet on which the egg was laid (Fig. 4). First indications of the development of a compact tube at the centre of the web occurred five days after the larva hatched, probably after the first moult. From this stage onwards the larvae eat whole sections of the compound leaf, and large larvae even consume the petioles. Older larvae construct a compact silk tube, open only at the head end, into which are spun pellets of dark brown excrement (Fig. 5). To do this, the larva turns inside its tube and picks up the pellets of excrement with its mandibles. It turns again and places the pellets $1-5 \mathrm{~mm}$ outside the opening of the tube. The excrement is then fixed in position with new strands of silk and pressed compact using the head and thorax. The tube, particularly towards maturity, often hangs freely suspended between parts of the hostplant, or other plant species, in a trellis of silk strands. Maximum dimension of the complete web may extend to $15 \mathrm{~cm}$. The tube itself reaches a length of $2.5 \mathrm{~cm}$ and is solid and quite hard, requiring definite pressure to make it collapse. To feed, the larva partly or completely leaves its tube, moving on the strands of silk. It may either consume from the edge individual leaflets which are still attached to the plant, or the petiole is severed and the food dragged back towards the tube: the leaflets then hang in the web and are consumed thereafter (Fig. 5). The larvae may remain motionless on the web outside the tube for long periods, with intermittent feeding activity. Feeding was observed to be particularly rapid at very high temperatures (a maximum of $43^{\circ} \mathrm{C}$ measured in full sunshine just above ground level), but larvae also feed at night. The attitude of the larva in its web varies randomly from "normal" (ventral side down) to "upsidedown". If disturbed, the larva moves rapidly backwards into its shelter. Although the larvae are normally solitary, about $30 \%$ live together in groups of 2-3, with the tubes more or less fused together at the centre of a shared net. This corresponds well with observations made on distribution of eggs (see 3.5.5). 
Older larvae regularly exhaust the supply of food in the vicinity of their tube. It could not be ascertained whether they then move to a new site and construct a fresh shelter, although this seems probable. One larva (16 mm body length), which had no remaining Peucedanum leaves within $30 \mathrm{~cm}$ of its tube, slowly extended its web so that it was more than $6 \mathrm{~cm}$ away from its shelter. This larva was seen to detach and consume a $1 \mathrm{~cm}$ long piece of Festuca leaf-blade. This can be regarded as a case of compensatory feeding, comparable to the behaviour of certain diprionid sawflies, which although normally oligophagous on a single host plant genus, may feed on neighbouring plants of different genera when their usual host is entirely defoliated (e. g. Neodiprion sertifer (GeOFfroy, 1785) on spruce instead of pine; PsCHORN-WALCHER 1982).

\subsection{Discussion}

One of the most striking biological differences between the Megalodontesidae and the Pamphiliidae is the exclusive attachment of Megalodontes larvae to herbaceous plants (mainly, or perhaps only, Apiaceae), whilst Pamphiliidae have mainly woody hostplants, either conifers (Cephalciinae) or angiosperms (Pamphiliinae), particularly of the orders Rosales and Fagales. The few Pamphiliidae which do not use trees or shrubs as hosts, seem to be associated only with Rosaceae (e. g. Pamphilius jucundus (Eversmann) on Fragaria, Onycholyda sertata (Konow) on Filipendula ulmaria). At present, the only definite hostplant records for Megalodontesidae are of various genera of Apiaceae (Stritt 1937, Vershutskij 1973, Ermolenko 1984, Pschorn-Walcher 1990, Taeger 2002). Possibly also reliable are the statements by GussakowskiJ (1935), unfortunately without indication of the source of the information, that Ruta and Haplophyllum (Rutaceae) are hosts of no less than three Megalodontes species (M. xanthosomus Zhelochovtsev, 1927; M. nitens (Freymuth, 1870); M. skorniakowii (FreYmuth, 1870)) in Central Asia. The intriguing record of larvae of Megalodontes fabricii (LeACH, 1817) on Salvia nemorosa L. (Lamiaceae) in Europe in MóczÁr \& ZомвоRI (1973) requires confirmation. Our observation (see 3.6) of an instance of compensatory feeding by a larva of $M$. thor shows that particular care must be taken in identifying hostplants of Megalodontes larvae. It is possible that the record from Salvia was based on mature larvae whose webs happened to be suspended in Salvia, but the actual foodplant (possibly a species of Apiaceae) in the immediate vicinity had been completely consumed.

The most obvious behavioural difference between adult Pamphiliidae and Megalodontesidae is feeding of the latter (probably all species) at inflorescences, whilst Pamphiliidae adults are not known to feed at-all. Copulation during phases of feeding, especially on inflorescences, is widespread in several families of "Symphyta". The temporal separation of the two behaviour types in $M$. thor is noteworthy, because no similar behavioural pattern seems so far to have been noted in the Symphyta. Also remarkable are the overnight aggregations of males around females. On the other hand, the basic behaviour pattern of Megalodontes larvae closely resembles that of some Cephalciinae of the Pamphiliidae (Acantholyda, Cephalcia) on conifer hosts, which construct a silk web at the centre of which is a tube used as a shelter, to which needles are carried and then consumed (PsCHORN-WALCHER 1982). However, whilst presence of faeces in the walls of the tube is stated by Pschorn-WaLcher to result from a passive process in Cephalciinae, the larva of $M$. thor actively incorporates faecal pellets in its shelter (see 3.6).

Oviposition behaviour in $M$. thor includes the deposition of a clear secretion around the egg, which is similar to the behaviour of some Pamphilius spp. and Onycholyda sertata (Konow, 1903) (Pamphiliidae: Pamphiliinae) as recorded by Vikberg (2002). Whereas the secretion applied by 
some of the Pamphiliidae which VIKBERg studied is coloured and is applied in a species-characteristic pattern only to particular parts of the leaf or leaf-petiole, $M$. thor smears a transparent substance at random on parts of the whole underside of the leaflet around the egg. The presence of a few discrete threads of secretion, as around eggs of $M$. thor, was also observed by VIKBERG (2002) in Pamphilius aucupariae Vikberg, 1971. In neither the Pamphiliidae nor M. thor is the function of the smeared secretion or the strands clear. VIKBERG suggested that in Pamphiliidae the secretion may serve as a deterrent to egg-parasitoids or predators. The fibres around the egg of $M$. thor might however perform a quite different, purely mechanical function as "life-lines" for the newly emerged larva and a foundation for its first web. The larvae of Pamphilioidea lack abdominal prolegs and are therefore at considerable risk of falling from the extremely smooth leaf surfaces of hosts such as Peucedanum oreoselinum.

Many species of Symphyta with morphologically similar adults can be characterised more clearly using biological and / or larval morphological characters. As demonstrated below, characterisation of Megalodontes species in this way is possible. Several features of the behaviour of $M$. thor differ from $M$. cephalotes, as follows:

\section{M. thor;}

- $\quad$ eggs usually laid singly, less frequently 2-3 are laid by different females on different leaflets (rarely on same leaflet) of a compound leaf; on leaflet underside, but otherwise not localized (see 3.5.5).

- $\quad$ egg is gummed to leaf epidermis, and although a shallow incision is possibly made in the leaf epidermis with the ovipositor, the egg chorion is not folded into this (see 3.5.5).

- Larval hosts: Peucedanum oreoselinum, probably also other Peucedanum species (P. alsaticum, P. carvifolia) (see 3.1).

- larvae mostly solitary (see 3.6).

- $\quad$ period of adult activity in a single local population lasts about 2 months (see 3.3).

- $\quad$ adults feed almost exclusively at yellow inflorescences, particularly of Ranunculus spp. and Asteraceae, never at the (white) inflorescences of the hostplant (see 3.5.1).

M. cephalotes; based primarily on data in PsCHORn-WALCHer (1990);

- $\quad$ eggs laid in clusters of 2-7 on underside of leaflet base.

- $\quad$ egg is attached to the leaf by a fold in the egg chorion inserted into a shallow slit in the leaf-epidermis.

- Larval hosts: Laserpitium latifolium L., Laserpitium siler L. and Seseli libanotis (L.) KocH (Stritt 1937, Lorenz \& Kraus 1957, Pschorn-Walcher \& Altenhofer 2000). A record of $M$. cephalotes larvae on Peucedanum cervaria probably refers to M. panzeri (LeAch, 1817).

- young larvae feed gregariously.

- period of adult activity in a single local population lasts little more than 1 month.

- adults visit white and yellow inflorescences, regularly including the (white) umbels of the larval hosts. 
It is regrettable that no data are available on the biology of $M$. plagiocephalus, a species which morphologically closely resembles $M$. thor. $M$. plagiocephalus is one of the rarest Megalodontes species in Western Europe. In Germany, for example, there are very few records from BadenWürttemberg only. An investigation of its biology might best be attempted in more south-easterly regions of Europe where recent records have been more frequent.

Species such as Megalodontes thor that are xerothermophile and dependent in some way on open, treeless areas of vegetation, comprise only perhaps 4-8 \% of the Central European sawfly fauna. It is impossible at present to give a more precise estimate of the number of species that belong in this category, because there is a lack of reliable data on their biology and distribution, and much depends on how one defines "xerothermophile". A hindrance to further studies is the extremely local occurrence and / or rarity of many of these species. The importance to $M$. thor of sparse vegetation cover, with a correspondingly dry and hot microclimate, is illustrated by its favoured oviposition sites (see 3.5.5). As already indicated for the sawfly Abia nitens (Linnaeus, 1758) (Cimbicidae) by LisTon \& SРÄTH (2006), changes in vegetation structure resulting from increasing eutrophication of its habitats may be playing a major role in the decline of $M$. thor in Central Europe.

\section{Acknowledgements}

Dr S. M. Blank (Müncheberg) made valuable suggestions on an early version of the manuscript. Dr M. Gossner (Jena) identified Phymata crassipes. Recent records of M. thor in Germany were made available by H. Kolbeck (Weng), Dr M. Kraus (Nürnberg) and Dr A. Taeger (Müncheberg). Dr S. Schmidt allowed us to reproduce his photo of $M$. thor in copula. We are indebted to the Government of Lower Bavaria (Landshut) for issuing permits for work on the Nature Reserves at Rosenau and Goben.

\section{References}

Blank, S. M.; Deters, S.; Drees, M.; Jänicke, M.; Jansen, E.; Kraus, M.; Liston, A. D.; Ritzau, C. \& Taeger, A. 2001: Symphyta. Pp. 8-27. - In: Dathe, H. H.; Taeger, A. \& Blank, S. M. (eds): Verzeichnis der Hautflügler Deutschlands (Fauna Germanica 4). - Entomologische Nachrichten und Berichte, Beiheft 7.

Ermolenko, V. M. 1984: K faune rogochvostov i pililschtschikov (Hymenoptera, Symphyta) Kryma. Taksonomija i Zoografija nasekomych, Kiev Nukova dumka 1984: 47-56.

Gussakovskij, V. V. 1935: Insectes Hyménoptères, Chalastrogastra 1. - Fauna SSSR 2 (1): 1-453.

Hiendlamar, A. 1878: Tarpa spissicornis Kuug. - Mittheilungen des Münchener Entomologischen Vereins 2: 163 .

Jervis, M. \& Vilhelmsen, L. 2000: Mouthpart evolution in adults of the basal, 'symphytan', hymenopteran lineages. - Biological Journal of the Linnean Society 70 (1): 121-146.

Kriechbaumer, J. 1878: Zur Lebensweise der Tarpa spissicornis Klg. - Entomologische Nachrichten, Quedlinburg 4 (13): 169-170.

Liston, A. D. \& Sрӓтн, J. 2006: On the Biology of Abia nitens (Linné, 1758): a Thermophile Sawfly with a Diurnal Larval Feeding-Pattern (Hymenoptera: Symphyta: Cimbicidae). Pp. 129-138. - In: BLANK, S. M.; Schmidt, S. \& TAeger, A. (eds): Recent Sawfly Research: Synthesis and Prospects. - Goecke \& Evers, Keltern.

Lorenz, H. \& Kraus, M. 1957: Die Larvalsystematik der Blattwespen (Tenthredinoidea und Megalodontoidea). - Abhandlungen zur Larvalsystematik der Insekten 1: 339 + vi pp.

Móczár, L. \& Zombori, L. 1973: Levéldarázs-alkatuak I. - Hymenoptera I (II). Tenthredinoidea I. - Fauna Hungarica 111: 1-128, 1-4 pp. 
Pschorn-Walcher, H. 1982: Unterordnung Symphyta, Pflanzenwespen. Pp. 4-196, 232-234. - In: Schwenke, W. (Hrsg.): Die Forstschädlinge Europas 4. - Paul Parey, Hamburg und Berlin.

Pschorn-Walcher, H. 1990: A brief note on the biology and larvae of Megalodontes klugi Leach (Hym.: Megalodontidae). - Mitteilungen der schweizerischen entomologischen Gesellschaft 63: 303-307.

Pschorn-Walcher, H. \& Altenhofer, E. 2000: Langjährige Larvenaufsammlungen und Zuchten von Pflanzenwespen (Hymenoptera, Symphyta) in Mitteleuropa. - Linzer biologische Beiträge 32 (1): 273-327.

Scheuerer, M. \& Späth, J. 2001: Die Gefäßpflanzenflora und Magerrasenvegetation des Naturschutzgebietes "Rosenau" bei Mamming an der Isar sowie Maßnahmen im Rahmen eines LIFE-Projekts zu ihrem Erhalt. - Laufener Seminarbeiträge, Bayerische Akademie für Naturschutz und Landschaftspflege, Laufen/Salzach, 3/01: 95-120.

Stritt, W. 1937: Pontische Blattwespen (Megalodontes Latr.) an pontischen Pflanzen (Hym., Tenthr.). - Beiträge zur naturkundlichen Forschung in Südwestdeutschland 2: 217-220.

TAEger, A. 2002: The Megalodontesidae of Europe (Hymenoptera, Symphyta). Pp. 461-480. - In: Vittasaari, M. (ed.), Sawflies (Hymenoptera, Symphyta) I. A review of the suborder, the Western Palaearctic taxa of Xyeloidea and Pamphilioidea). - Tremex, Helsinki.

Taeger, A.; Altenhofer, E.; Blank, S. M.; Jansen, E.; Kraus, M.; Pschorn-Walcher, H. \& Ritzau, C. 1998: Kommentare zur Biologie, Verbreitung und Gefährdung der Pflanzenwespen Deutschlands (Hymenoptera, Symphyta). Pp. 49-135 \& Taf. 3. - In: Taeger, A. \& Blank, S. M. 1998 (Hrsg.): Pflanzenwespen Deutschlands (Hymenoptera, Symphyta). Kommentierte Bestandsaufnahme. - Goecke \& Evers, Keltern.

Taeger, A.; Blank, S. M. \& Liston, A. D. 2010: World Catalog of Symphyta (Hymenoptera). - Zootaxa 2580: 1-1064.

Vershutskij, B. N. 1973: Opredelitel' lichinok rogokhvostov i pilil'shchikov Sibirii i Dal'nego Vostoka. [Keys to the larvae of the wood- wasps and sawflies of Siberia and the Soviet Far East]. - Nauka, Moscow: $140 \mathrm{pp}$.

Vittasaari, M. 2002: The suborder Symphyta of the Hymenoptera. Pp. 11-174. - In: Virtasaari, M. (ed.), Sawflies (Hymenoptera, Symphyta) I. A review of the suborder, the Western Palaearctic taxa of Xyeloidea and Pamphilioidea). - Tremex, Helsinki.

Vikberg, V. 2002: Rearing experiments on Finnish species of Pamphiliidae (Hymenoptera), with special emphasis on the egg laying behaviour. Pp. 439-459. - In: ViITASAARI, M. (ed.), Sawflies (Hymenoptera, Symphyta) I. A review of the suborder, the Western Palaearctic taxa of Xyeloidea and Pamphilioidea). - Tremex, Helsinki.

Authors' addresses:

ANDREW D. LISTON

Senckenberg Deutsches Entomologisches Institut

Eberswalder Str. 90

15374 Müncheberg, Germany
Subject editor:

Dr. Jochen SpÄTH

Sossauer Str. 49

84130 Dingolfing

Germany
Dr. A. TAeger 

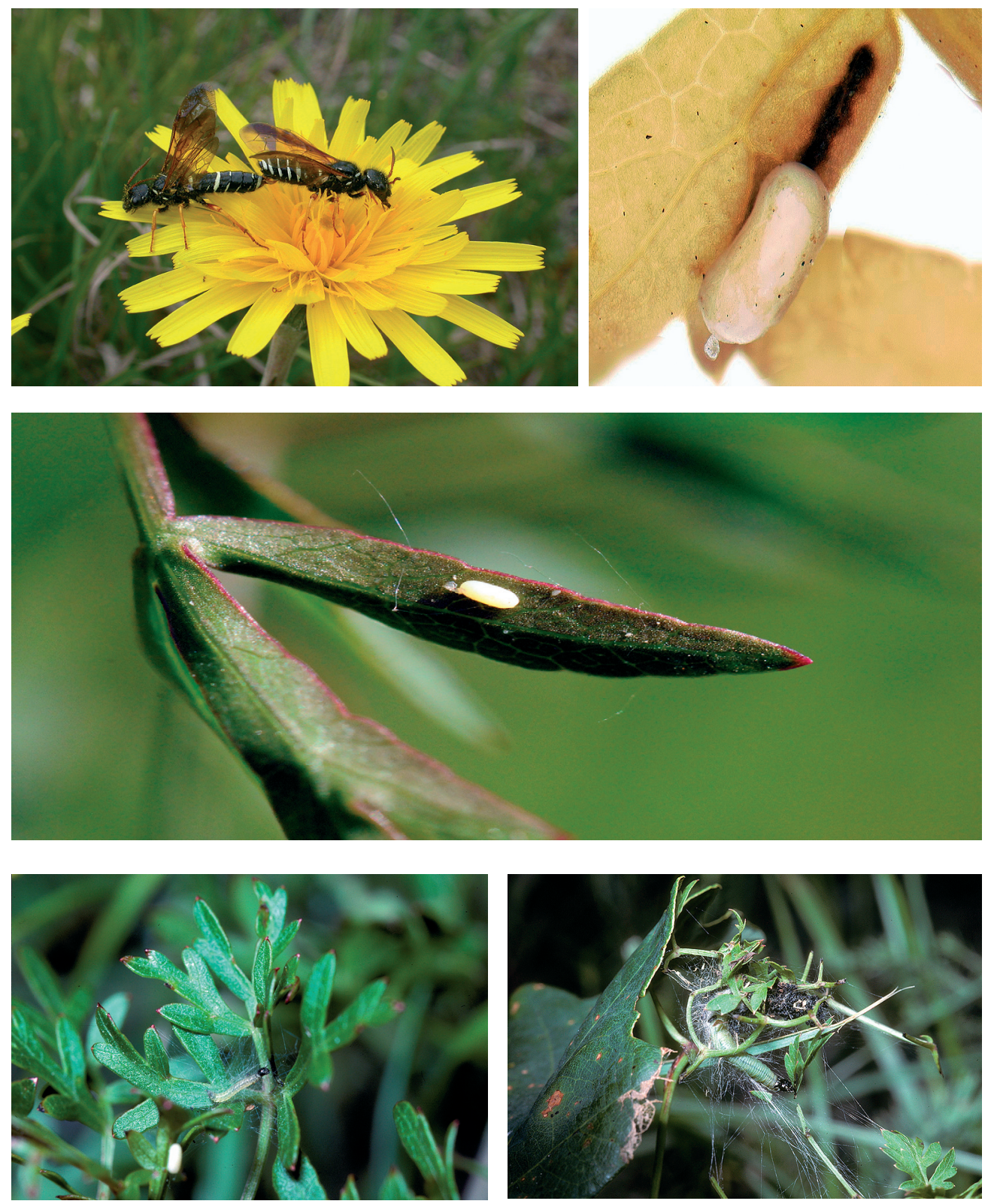

Figs 1-5. Megalodontes thor. All photos taken at Rosenau Nature Reserve, Bavaria. - Fig. 1: Copula (male at left) on Leontodon sp. inflorescence,; photo by S. Schmidt. - Fig. 2: Egg (conserved in ethanol) on underside of leaflet of Peucedanum oreoselinum, with discolouration of leaf-tissue possibly resulting from its disruption during oviposition; photo by Liston. - Fig. 3: Egg with strands of secretion; photo by Späth. - Fig. 4: Young larva, probably $2^{\text {nd }}$ instar; length ca $5 \mathrm{~mm}$. The web is made of rather loose strands of silk and no tube has yet been made; photo by Späth. - Fig. 5: Mature larva; length ca $25 \mathrm{~mm}$. The web is used by the larva for movement between the foraging site and the tube. The compact, hard tube (shelter), into which numerous pellets of excrement are incorporated, hangs in the web, surrounded by detached pieces of the host that will soon be eaten; photo by Späth. 